\title{
The Knowledge and the Use of Educational Applications from University Students in Spain and the Czech Republic
}

\author{
El conocimiento y el uso de las aplicaciones educativas de los estudiantes \\ universitarios de España y la República Checa \\ El coneixement i l'ús de les aplicacions educatives dels estudiants universitaris \\ d'Espanya i la República Txeca
}
Patricia de-Casas-Moreno ${ }^{1, *(\odot)}$, Mari-Carmen Caldeiro-Pedreira ${ }^{2}{ }^{\circledR}$, Tereza Havránková3 ${ }^{30}$

\author{
1 | Universidad Antonio de Nebrija, Madrid, Spain \\ 2 | University Santiago of Compostela, Lugo, Spain \\ 3 | University of West Bohemia, Chequia, Czech Republic \\ *Corresponding author: pcasas@nebrija.es (Patricia de-Casas-Moreno)
}

Received: 07/17/2020 | Accepted: 04/23/2020 | Published: 06/24/2020

Citation: de-Casas-Moreno, P., Caldeiro-Pedreira, M.C., \& Havránková, T. (2020). The Knowledge and the Use of Educational Applications from University Students in Spain and the Czech Republic. Research in Education and Learning Innovation Archives, 24,39-55.

$10.7203 /$ realia.24.16696

Copyright: The Authors. Open Access: This article is distributed under the terms of the Creative Commons Attribution-NoDerivatives 4.0 International licence (CC BY-ND 4.0)

\section{Funding: R+D Project} "Youtubers and Instagrammers: media competence in emerging prosumers"

(RTI2018-093303-B-I00)
ABSTRACT: Technological evolution has led to many changes at both professional and academic levels. The inclusion of Information and Communication Technologies (ICT) has caused dizzying changes in the different contexts of life (educational, professional, social). More and more applications are being downloaded by users to their mobile devices, both for entertainment and training. For this reason, this study is based on the need to assess the knowledge and attitude of university students towards downloading existing educational applications. In this way, the use and frequency of these tools in the teaching-learning process of the students will be analyzed. In order to carry out this study, the quantitative methodology has been taken into consideration with the collection of data with a sample conformed by a total of 278 students of Higher Education between Spain and the Czech Republic. For this purpose, a survey has been prepared as an instrument of analysis, which has been validated by experts in the field. Among the most outstanding results, it can be seen that in both countries, students download educational apps to a greater or lesser degree, according to their interest and subject matter. Likewise, there is a lack of competences and skills in the use of these new technologies as a training complement. Based on this, we propose the continuous training of students and teachers in the knowledge and pedagogical use of ICT in general and educational apps in particular.

KEYWORDS: Digital society; Higher education; educational applications; knowledge; training; quantitative methodology

RESUMEN: La evolución tecnológica ha propiciado múltiples cambios tanto a nivel profesional como académico. La inclusión de las Tecnologías de la Información y la Comunicación (TIC) han provocado cambios vertiginosos en los diferentes contextos de la vida (educativo, profesional, social, etc). Cada vez son más las aplicaciones que se descargan los usuarios en sus dispositivos móviles, tanto para entretenerse como para formarse. Por este motivo, el presente estudio parte de la necesidad de valorar el conocimiento y actitud de los estudiantes universitarios frente a las descargas de las aplicaciones educativas existentes. De este modo, se analizará el uso y frecuencia de estas herramientas en el proceso de enseñanza-aprendizaje de los discentes. Para llevar a cabo este estudio, se ha 
tomado en consideración la metodología cuantitativa con la recolección de datos con una muestra conformada por un total de 278 estudiantes de Educación Superior entre España y República Checa. Para ello, se ha elaborado una encuesta como instrumento de análisis, la cual ha sido validada por expertos en la materia. Entre los resultados más destacados, se puede apreciar que en ambos países los alumnos realizan descargas de Apps educativas en mayor o menor grado, según su interés y temática de estudio. Asimismo, se observa una falta de competencias y habilidades en el uso de estas nuevas tecnologías como complemento formativo. En base a esto, se propone la formación continua del alumnado y del docente en el conocimiento y uso pedagógico de las TIC en general y de las Apps educativas en particular.

PALABRAS CLAVE: Sociedad digital; Enseñanza superior; aplicaciones educativas; conocimientos; capacitación; metodología cuantitativa

RESUM: L'evolució tecnològica ha propiciat múltiples canvis tant en l'àmbit professional com acadèmic. La inclusió de les Tecnologies de la Informació i la Comunicació (TIC) ha provocat canvis vertiginosos en els diferents contextos de la vida (educatiu, professional, social, etc.). Cada vegada són més les aplicacions que es descarreguen els usuaris en els seus dispositius mòbils, tant per a entretenir-se com per a formar-se. Per aquest motiu, aquest estudi parteix de la necessitat de valorar el coneixement i l'actitud dels estudiants universitaris davant les descàrregues de les aplicacions educatives existents. D’aquesta manera, s'analitzarà l'ús i freqüència d'aquestes eines en el procés d'ensenyament-aprenentatge dels discents. Per a dur a terme aquest estudi, s'ha pres en consideració la metodologia quantitativa amb la recopilació de dades amb una mostra conformada per un total de 278 estudiants d'educació superior entre Espanya i República Txeca. Per a això, s'ha elaborat una enquesta com a instrument d'anàlisi, que ha estat validada per experts en la matèria. Entre els resultats més destacats, es pot apreciar que en tots dos països els alumnes realitzen descàrregues d'Apps educatives en major o menor grau, segons el seu interès i temàtica d'estudi. Així mateix, s'observa una falta de competències i habilitats en l'ús d'aquestes noves tecnologies com a complement formatiu. Prenent com a base això, es proposa la formació contínua de l'alumnat i del docent en el coneixement $i$ ús pedagògic de les TIC en general i de les Apps educatives en particular.

PARAULES CLAU: Societat digital; Ensenyament superior; aplicacions educatives; coneixements; metodologia quantitativa

\section{Practitioner Notes}

\section{What is already known about the topic}

- ICTs and the emergence of the Internet have brought about unprecedented changes, particularly in the field of education and training. More and more applications are being downloaded to study, review, train and entertain at the same time. Thus, it is important to know the knowledge of university students, as well as their use of them.

\section{What this paper adds}

- To understand the use of educational applications by students, as well as new methodologies of mobile learning thanks to the emergence of ICT.

\section{Implications of this research and/ or practice}

- To strengthen students' media competences and skills in order to achieve a critical and responsible society in the use of ICT and in turn, in the use of downloaded applications.

\section{INTRODUCTION}

The presence of multiple digital devices, all of which provide means of communication, requires new knowledge not only regarding their operation but also in terms of their appropriate usage.

Digital society demands new ways of communication and interaction. The media ecosystem (Canavilha, 2011), which is also referred to as a digital ecosystem (Albaladejo-Ortega \& Sánchez-Martínez, 2019), is defined as a large group of 
devices and applications that are connected via different networks and tools. In other words, these can be educational or gaming applications that can be accessed by the general public, but mainly by adolescents. In this sense, reference can be made to the social globalization that occurs thanks to the ongoing, daily, process of digitization (Granado-Palma, 2019).

Despite digital globalization, it is important to stress that knowing how to use/operate technology does not necessarily equate appropriate usage. In addition, being born in the Digitized era does not always lead to the development of critical and rational awareness of technology. Especially in the case of young people who can access information in a completely different way than the past generations, it is necessary to learn about the coexistence of different media and to train people who belong to what is referred to as "digital citizenship" (Gozálvez, 2015). Nowadays, men and women are capable of consuming technology without the ability to use apps efficiently. In this sense, there is an urge to make the transition from passive to active usage of technology. The digital generation demands "prosumers" (García-Ruiz, Ramírez-García, \& Rodríguez-Rosell, 2014) or "pro designers" (Hernández-Serrano, Renés-Arellano, Graham, \& Greenhill, 2017), rather than content producers. In other words, it concerns a group of people who are capable of learning and have the ability to promote learning comprehension (Unionews, 2016). Both natives and digital natives (Fernández-García, Blasco-Duatis, \& Caldeiro-Pedreira, 2016) should know about the harmful and positive aspects of technology and applications.

In this context, and due to the unstoppable speed, innovations flooding our lives, it is convenient to know the applications which are used by students in higher education.

Knowing that the students can download applications, it is interesting to find out what types of educational apps they download, what they use them for, and what educational-pedagogical aspects can the applications offer. A question of great importance is what different national and international organizations do in order to achieve digital competence and literacy.

\subsection{The App generation: beyond technology}

According to the ONTSI "National Observatory of Technology and Information Society" digitalization affects all aspects of our lives. It has been implemented in our homes, classrooms, and society in general. Undeniably, screens have taken over our daily work and are the current media ecosystem (Canavilha, 2011); in this sense, we have become multitasking individuals, who are able to review different screens while performing other activities. At the same time, the number of hours we dedicate to different mobile devices increases considerably on Saturdays and Sundays. On weekdays, we spend about 3 hours using digital technologies. In this context, it is appropriate to establish a measurable and rational way of how to use technology, so it is beneficial for us. Educational intervention is suggested, social and technological changes call for new ways of teaching and learning that suit the current situation (García-García \& Rey-Barbáchano, 2012), as these teachers; app developers INTEF (2017), for example, point out, facilitating programming with different languages and allowing collaborative work.

New tools and apps available require new methodologies and intervening roles in the educational field. With all this, it seeks to meet the needs of the "Generation App". Gardner and Davis (2014) speak about a generation of young people whose intimacy, creativity, or even their identity has interfered with the devices they use. It is a group of people who were born surrounded by technology. They use technology daily, and sometimes they can become addicted to it. Despite the negative and harmful aspects, the positives of technology can be the fact that apps, the Internet and the digital interconnection allow people to work effectively, i.e., focusing more on the 
know-how, how to design and apply, rather than doing merely repetitive and memorial tasks (Ramírez-Mera \& Barragán-López, 2018).

\subsection{Emerging needs}

The digital context requires a scope of new skills and competencies that can supply the needs that consistently and continuously emerge. In this sense, the Intef in the Common Framework of Digital Teaching Competence (2017) (INTEF, 2017) defines digital competencies as a set of skills that need to be developed in the 21st century. In the case of teachers, the framework points out the necessity to improve their educational practice" (INTEF, 2017, p. 3). In a general social context, citizens must be able to read audiovisual content they receive and decode it correctly. Especially when we have applications that can be installed into almost all electronic devices that allow us to know our body temperature, blood type, translate into different languages or allow us to explore almost all the countries. In this context, the most reasoned alternative to develop is the "critical competence" (Caldeiro-Pedreira \& Aguaded-Gómez, 2015), that is, the ability to reflect critically and autonomously on the massive amount of information that we are exposed to. A capacity that needs to be developed for the infotoxication environment (Aguaded, 2014) seems to take over the everyday social reality.

In 2018 the School Council understood the importance of such a need, and in 2018 the Permanent Commission issued Opinion 11/2018 of the Ministry of Education, Culture, and Sport (MECD, 2018). The document specifies different competence levels and the need for teacher training. Teacher training should be aimed at new emerging competencies as well as literacy that enables us to reach the minimum level of digital competence required for coexistence in the digital society.

DigiComp Report is another document that implies the emerging needs. The report is divided into five areas, including a part on 21 digital competencies that all citizens must develop. These are essential skills for the personal and professional development of natives (Fernández-García et al., 2016). Regardless of their knowledge, the use of technology, and numerous apps, citizens must reach a basic level of digital competence that allows them not only to be able to use the tools they have but also to know about the potential and danger.

In this sense, the capacities, first and foremost, must be inclusive and bridge the gap instead of widening it. Then, they must be based on respecting human rights and the dignity of men. All this helps to generate new questions about the meaning of literacy in the present day and age (Replantear las capacidades en alfabetización en un mundo digital, 2017). Digital Literacy is a "continuous renewal of abilities to learn and communicate" (Carolina-Martí, Agostino, de Cabo, \& Sanz-Valero, 2008), defines digital literacy not only as the knowledge that helps us understand how technology is used but also as a practice that enables us to produce contents and optimize the potentialities of different applications. A need that becomes real in different contexts such as the one referred to in the development of digital competition within the framework of DigComp (Vuorikari, Punie, Carretero-Gomez, \& Van-Den-Brande, 2016) or Heritage-themed Apps (Ibañez-Etxeberría, Kortabitarte, Castro, \& Gillate, 2019).

\subsection{Reformulating education. Is it possible to use Apps in the classroom?}

In this context, it is indisputable that there is a need to redesign education and transform pedagogy, so that these new methodologies are applied, especially within the pedagogical faculties. Currently, "Education experiences an era of redefinition and reconversion characterized by high technological development and profound social changes" (Sánchez-López, Pérez-Rodríguez, and Fandos-Igado, 2019, p. 223). The changes imply that new approaches can satisfy educational needs and apply an innovative and current format. It is essential to redesign public policies in order to 
satisfy the digital society (Bizelli, 2017), a demand that is justified at a time when citizens download applications to handle different life situations. Although reality confirms urgent needs for training, curriculums continue to be anchored in the heavy use of traditional methodologies through which they intend to reach crucial pedagogical objectives inappropriately and improperly. They are not taking into account the reality and the needs society has to face. Furthermore, it has been committed to the integration and construction of collective learning that requires «a curriculum and rigorous planning» for more than five years (García-García and Rey-Barbáchano, 2012, p. 32). The transformation must occur horizontally for students in their learning and teachers in their teaching methods.

Many applications are used in Spain, ranging from translators to applications that perform calculations or facilitate communication. Besides, there are other app categories related to gaming, education, traveling, photography, video, or music. In general, the indicators show that the use of mobile applications is carried out for increasingly prolonged periods and is not exclusively limited to the young population, even though it is the young generation responsible for spreading their use.

It is convenient to carry out a brief analysis of websites where it is possible to find educational resources and applications that could be implemented and used in the education of the young generation. There are several projects in Spain, such as for example the Guappis Project that seeks a way to integrate mobile phones as a teaching-learning tool or Edutabletas, a project that aims to give new impetus to mobile learning (Noguera-Fructuoso, 2015).

In the field of higher education, collaborative methodologies are being implemented in Web 2.0: an implementation that students value positively (Rodrigo-Cano, Gómez, \& García-Moro, 2019).

\section{MATERIAL AND METHODS}

In terms of the theoretical part of this study, it is essential to know to what extent the development of digital skills is essential for students, professionals, and families, as well as what content is most important in promoting digital literacy.

The data collected during the research come from the Spanish and Czech context. Despite the geographical differences, both countries share similarities in the field of higher education.

Both countries stress the importance of competence and try to establish a clear line of continuity between knowledge acquired inside and outside the classroom experience/social interaction. In the Spanish and Czech contexts, it is assumed that educational applications can bridge the gap between formal and informal education.

In addition, there are three educational centers immersed in Apple's "For All" program in both countries. It is an initiative that implies that "anyone can learn to design applications for mobile devices."

This study is based on the need to assess university students' knowledge and attitude towards downloading existing educational applications. In this way, the use and frequency of these tools in the teaching-learning process of students will be analyzed. The research is based on a quantitative analysis using questionnaires for data collection. According to Buendía, Colás, and Hernández (1998), this instrument represents a suitable method for collecting opinions.

The questionnaire consists of 23 items, structured in a series of analysis parts: 1) Sociodemographic profile, 2) New technologies and use of educational technologies, 3) Knowledge of educational applications 4) Digital attitudes and skills 5) Educational applications. The descriptive-explorative analysis conducted is based on the responses of a total of 278 students in higher education in Spain and the Czech Republic. Furthermore, the questions derived for this study follow a line of questions with multiple 
options, as well as a Likert scale (where 1 is strongly disagree, 2 is strongly disagree, 3 is strongly agree and 4 is strongly agree). It was decided to opt for a four-score scale to avoid neutral values in the research.

In turn, the sample was intentionally established to ascertain the opinion of a specific group of (university) students. Without a doubt, this is an exploratory study, the basis for future lines of research, and comparisons of a more demanding universe.

On the other hand, the analysis instrument was validated by ten education experts, obtaining a high internal consistency index, 0.980 (Cronbach's Alpha). For the selection of the experts, the following characteristics were taken into account: doctors in education, proximity to teachers, researchers related to the thematic line of ICT, and the digital society. According to George and Mallery (2003, p. 231), when the coefficient is $>, 90$, the reliability of the instrument is excellent, and if it is $>, 80$ is good. In order to carry out a relevant analysis, the instrument was sent through the Google form (self-administered), and SPSS statistical software was used to interpret the results.

Finally, concerning the selection of the most used educational applications, during the month of June 2019, the Sensor Tower analysis instrument was applied to develop the questionnaire. This instrument analyses market trends, downloads of the most quoted applications, as well as positioning strategies. It is worth mentioning that the analysis parameters may vary over time due to user supply and demand. Thus, considering the two countries chosen for this study, we can highlight the 15 most downloaded mobile applications (Table 1):

Table 1. The most downloaded applications. Source: Sensor Tower.

\begin{tabular}{|c|c|c|c|c|}
\hline & Apps in Spain & Downloads & Apps in Czechia & Downloads \\
\hline 1 & Duolingo & $2 \mathrm{M}$ & $\begin{array}{l}\text { Duolingo: Naucte } \\
\text { se anglicky }\end{array}$ & $2 \mathrm{M}$ \\
\hline 2 & Calculator+ & $1 \mathrm{M}$ & Photomath & $1 \mathrm{cM}$ \\
\hline 3 & Photomath & $1 \mathrm{M}$ & $\begin{array}{l}\text { Bakalári - oficiální } \\
\text { aplikace }\end{array}$ & $800 \mathrm{~K}$ \\
\hline 4 & Kahoot & $1 \mathrm{M}$ & $\begin{array}{l}\text { WordBit Anglictina } \\
\text { (Automatické } \\
\text { ucení jazyka) }\end{array}$ & $800 K$ \\
\hline 5 & Google Classroom & $1 \mathrm{M}$ & $\begin{array}{l}\text { Minecraft: } \\
\text { Education edition }\end{array}$ & $800 K$ \\
\hline 6 & Peak: Brain games & $500 K$ & PlantNet & $800 K$ \\
\hline 7 & ClassDojo & $500 \mathrm{~K}$ & Lingokids & $800 K$ \\
\hline 8 & Babbel & $300 K$ & Google classroom & $800 \mathrm{~K}$ \\
\hline 9 & PlantSnap & $100 K$ & Kahoot & $800 K$ \\
\hline 10 & AeolCloud & $10 \mathrm{~K}$ & Quizlet & $800 K$ \\
\hline 11 & iPasen & $10 \mathrm{~K}$ & Math Learner & $800 \mathrm{~K}$ \\
\hline 12 & LingoKids & $10 \mathrm{~K}$ & Morské panny & $10 K$ \\
\hline 13 & Math Learner & $10 K$ & Násobilka IQ & $10 K$ \\
\hline 14 & Geogebra & $5 K$ & Edookit & $5 K$ \\
\hline 15 & SM Educamos familias & $5 K$ & Ceská gramatika & $5 K$ \\
\hline
\end{tabular}

Note: (M: milion; K: thousand)

\section{RESULTS}

The present study, as mentioned in the previous section, aims to assess the familiarity of university students and their attitudes towards educational apps and attitudes of 
university students to the use of educational applications. A comparative analysis was carried out in order to determine the socio-economic background of respondents, as well as to delve deeper by using exploratory-descriptive type questions a total of 278 students of higher education in Spain (146) and the Czech Republic (132) participated in the study. The respondents are from 4 European universities: Spanish universities (Antonio de Nebrija University- 59 and Santiago de Compostela University- 87) and 2 Czech universities (the University of West Bohemia- 86 and Ostravská Univerzita- 46).

\subsection{Socio-demographic profile}

In order to analyze the results of this comparative study between the two countries, it is vital to describe the significant differences between the socio-demographic profiles of the respondents.

Regarding age, it should be noted that the vast majority of respondents range between ages 18 and 24, respectively ( 81 Spain-115 R. Czech), and the rest of the respondents are students between 25 and 30 years of age (26 Spain- 10 R. Czech) Graph 1.

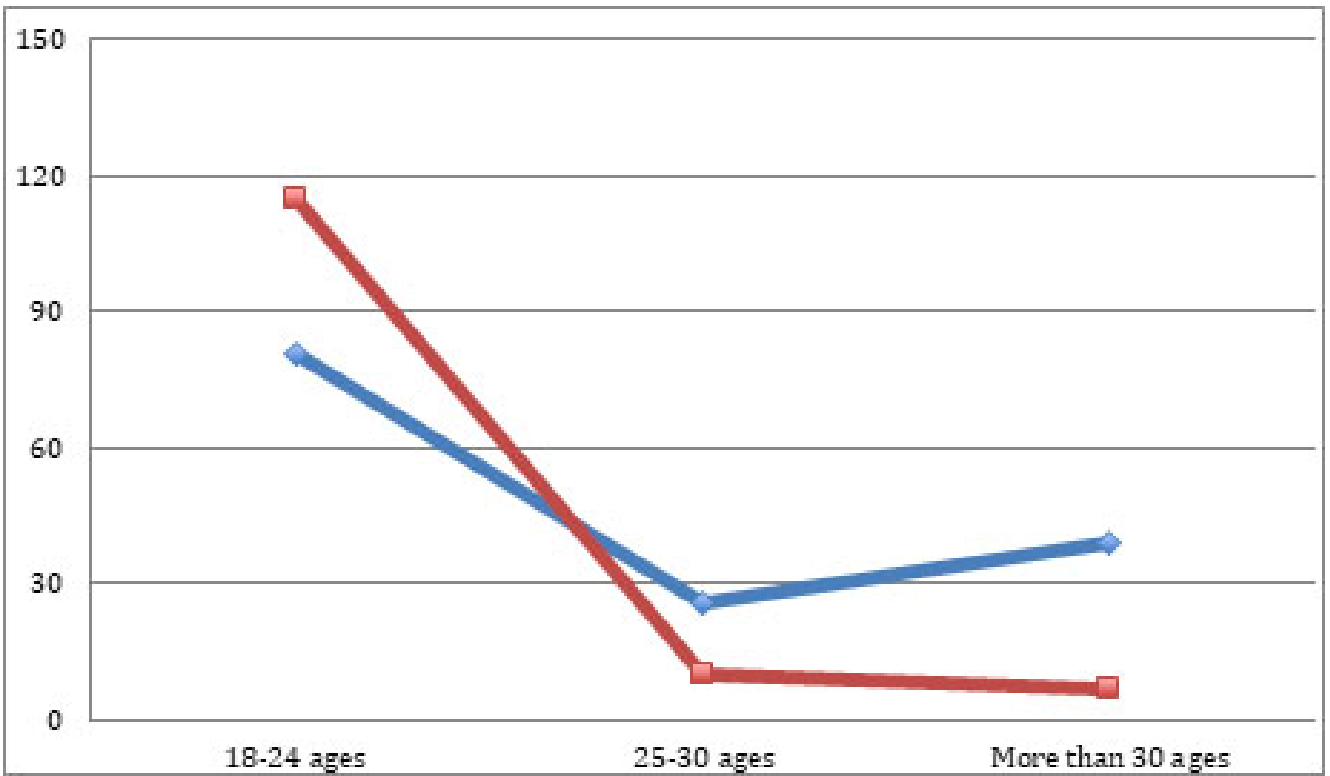

Graph 1: The age of the respondents -Spain - Czech Republic. Self-elaborated

As far as gender concerned, the female gender (114) prevails over the male (32) in Spain. The Czech Republic is similar, with women (85) outnumbering men (44). Only a total of 3 people have opted for the option "other."

Regarding the academic degrees, most of the respondents are enrolled in an undergraduate program (88 Spain- 93 R. Czech), followed by a Master's degree (58 Spain- 36 R. Czech). Only three people (all from the Czech Republic) state that they are pursuing a Ph.D. Likewise, respondents in both countries are studying education (Graph 2).

The data indicates that the average respondent in both Spain and the Czech Republic is a woman between the ages of 18 and 24, enrolled in a graduate program in an academic area of education.

\subsection{New technologies and the use of ICT}

Technological advances have caused changes in multiple fields, both professionally and socially. Thus, this study aims to address a series of issues related to the use of ICT by university students. The type of technological device students use most frequently differ in both countries: The Smartphone and tablet are more prevalent in Spain (smartphone 134 Spain-122 R. Czech) (tablet 26 Spain- 24 R. Czech) (Graph 3). 


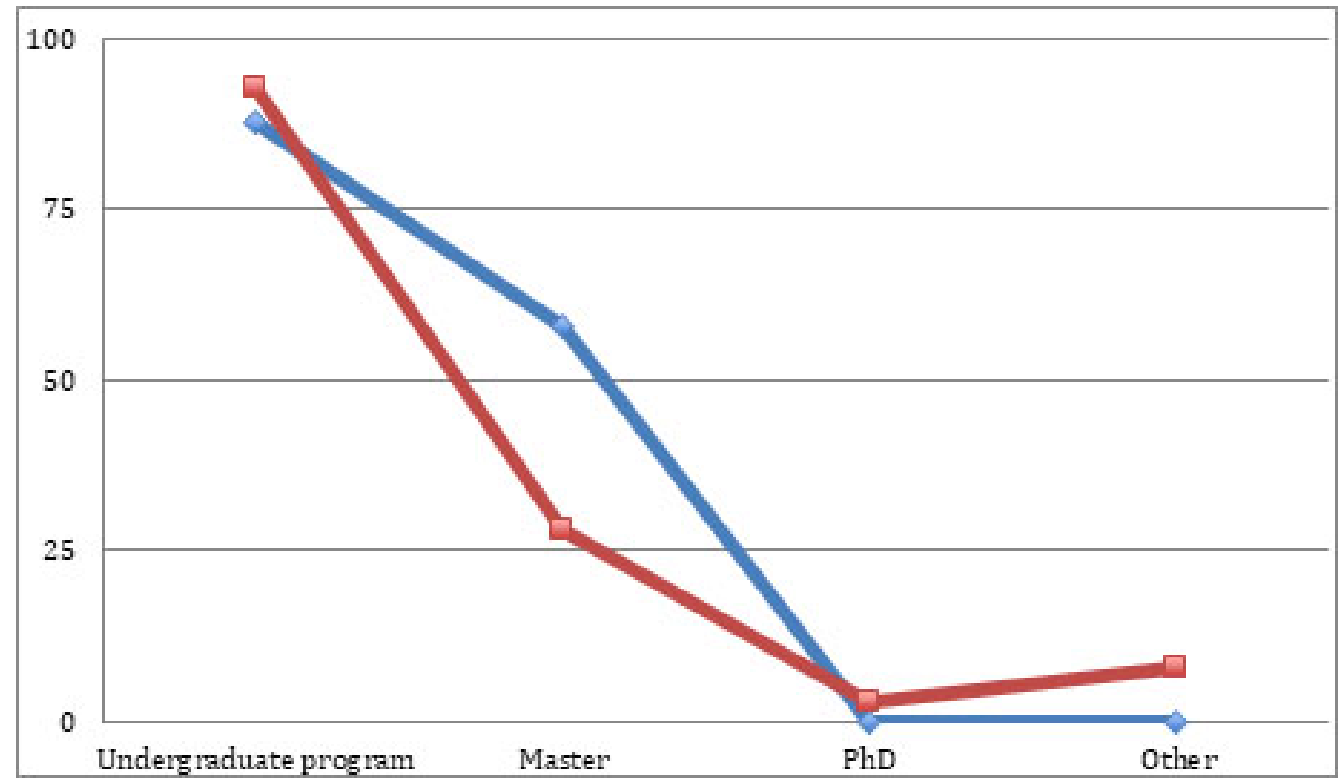

Graph 2: The type of degree the respondents are studying: Spain - The Czech Republic. Self-elaborated

Students also point out that they use these devices 3 hours a day in both cases (59 Spain- 48 R. Czech), followed by more than 4 hours a day (52 Spain- 43 R. Czech).

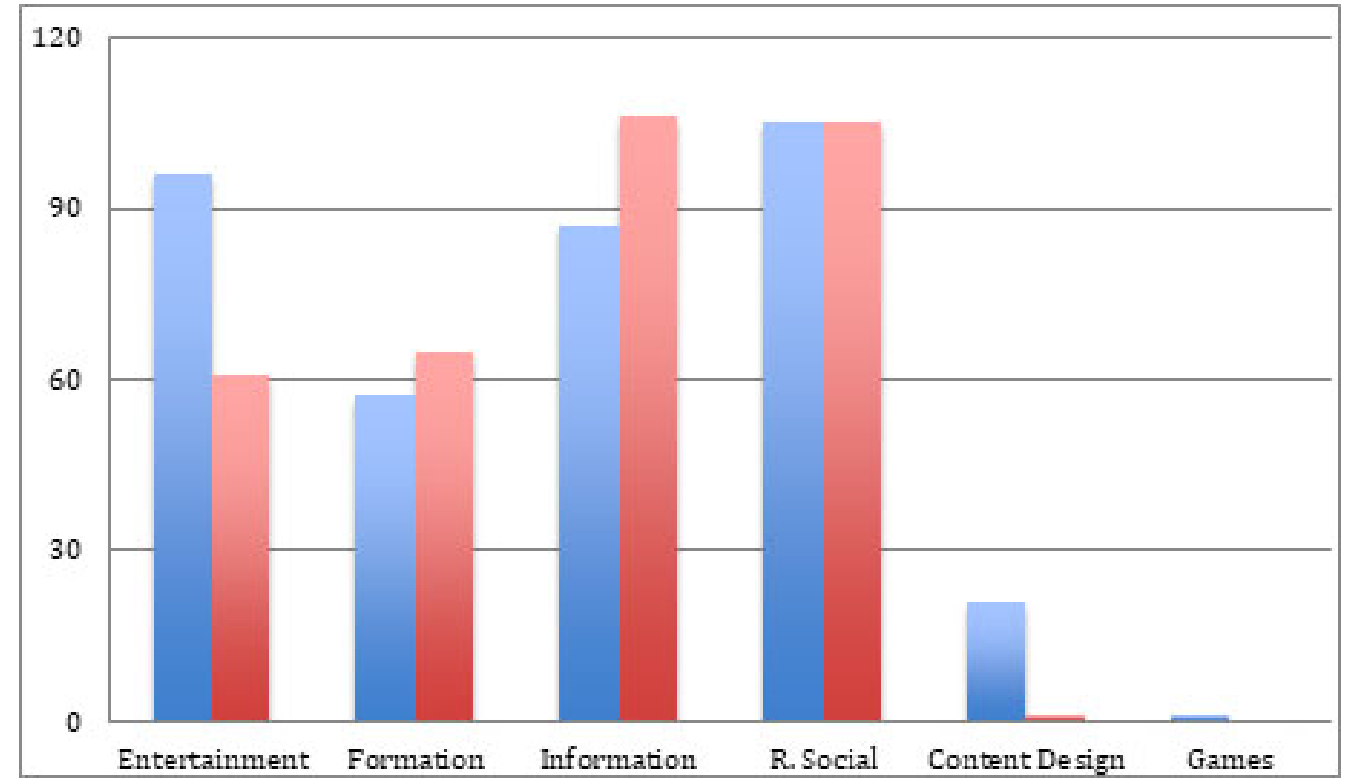

Graph 3: Devices used - Spain - Czech Republic. Self-elaborated

Furthermore, the software the respondents use most frequently is Android (106 Spain- 81 R. Czech) versus iOS (40 Spain- 51 R. Czech). Also, considering where the students use these devices, home is the most chosen option (141 Spain-116 R. Czech). However, there is a significant difference between the second most opted answer: students in Spain use phones on the street (44), and Czech students favor a university (95).

Finally, concerning the activities performed with these devices, it can be noted that in Spain, students use mobile devices for maintaining social relations (105), followed by entertainment (96) and information searches (87). On the other hand, students in 
the Czech Republic use mobile devices for information searches (106), followed by maintaining social relationships (105) and courses/training and education/school (65) (Graph 4).

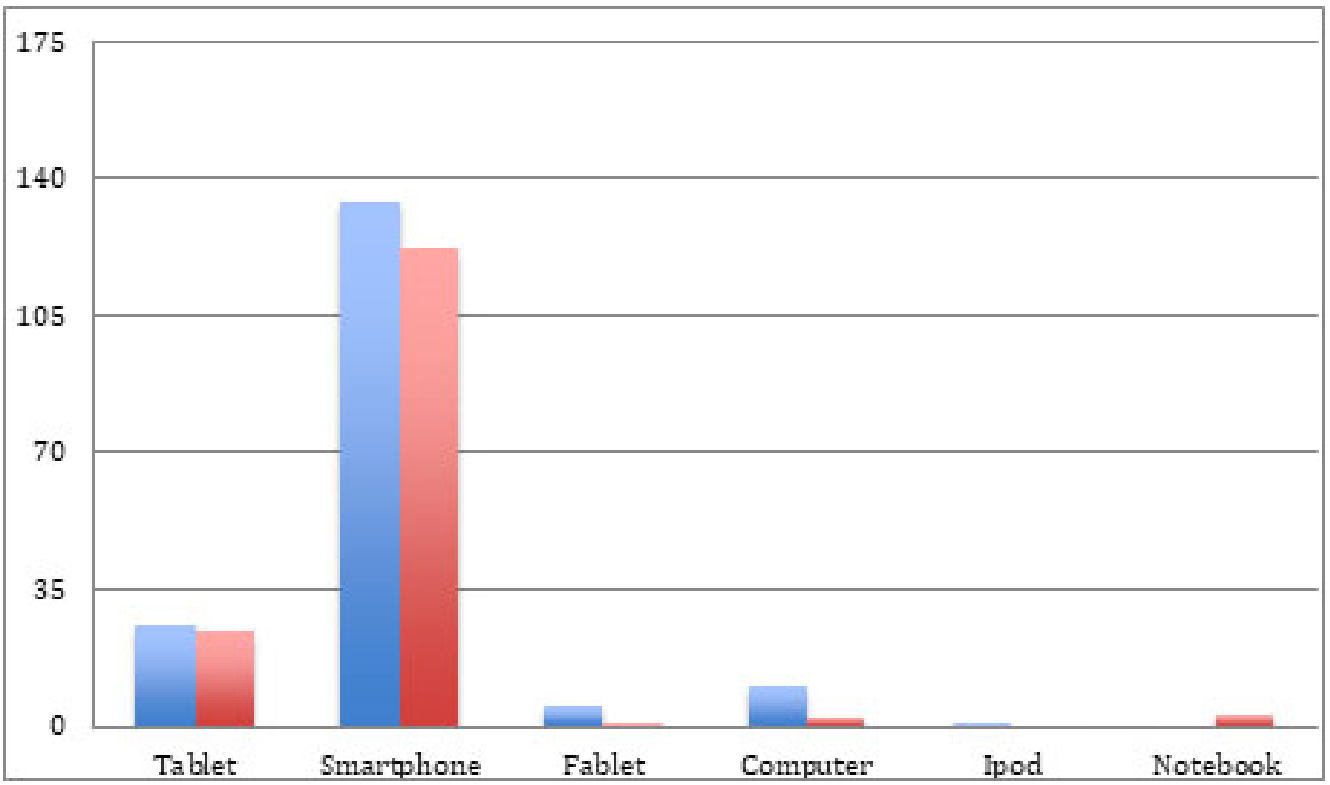

Graph 4: Activity performed with mobile devices Spain - Czech Republic. Self-elaborated

To sum up the profile of the typical respondent: he/she can be characterized as an individual who uses his/her Smartphone for 3 hours a day on average the software platform, they use Android. He/She mainly connects to his/her devices from home for purposes of entertainment, and he/she uses the device mainly for maintaining social relationships in the Spanish case and for searching information in the Czech case.

\subsection{Knowledge and approach to educational applications}

Every day many different applications are downloaded by students to start a selflearning or review the acquired knowledge. Therefore, it is necessary to inquire into the students' knowledge and personal approach to the use of educational applications. To do so, a series of unknowns are addressed, which will help to establish the basis of the study objectives. A high number of students claim to know what it is (144 Spain118 R. Czech). Furthermore, they indicate that they have downloaded an educational app before (95 Spain-105 R. Czech), some respondents even say they have downloaded 2 to 3 apps (54 Spain- 50 R. Czech). However, the responses show discrepancies between the two countries. While in Spain, the 27 respondents have not downloaded any educational apps, and 28 respondents have downloaded only one educational app, 25 respondents in the Czech Republic claim to have downloaded one educational app, and 20 said to have not downloaded a single educational app. To this, we must add that while the Spanish students say they do not use these applications frequently (52), followed by the answer "once a week" (39) and "2 to 3 times a week" (38), the Czechs claim to use the apps "once per week" (62), followed by "2 to 3 times per week" (30) and "never" (28). In this section, we can see the difference between the two countries, demonstrating that Czech students make greater use of educational technologies (Graph 5).

As far as the student app training is concerned, the respondents confirm being selftaught (81 Spain- 89 R. Czech), followed by obtaining relevant training at their university (50 Spain- 25 R. Czech). Also, they frequently claim to have used the educational apps in their field (69 Spain-114 R. Czech), compared to as a study complement (68 


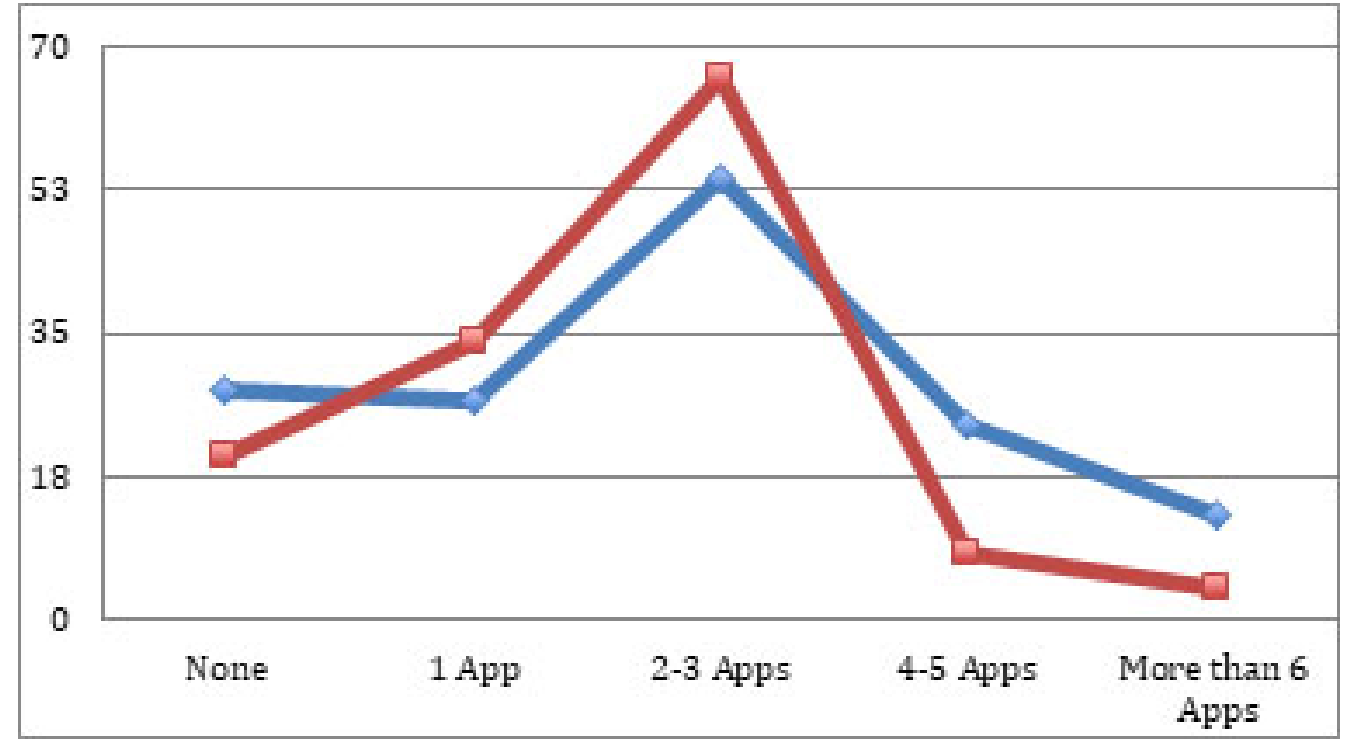

Graph 5: Downloaded apps according to the study - Spain- Czech Republic. Self-elaborated

Spain- 13 R. Czech).

To conclude and continue adding features to the student's profile, it can be said that the typical respondent is a student who knows and understands what an educational app is and who downloads about 2 and 3 apps into their mobile device. In the Spanish case, the student uses educational apps frequently, while in the Czech case, the student uses educational apps once a week. They are self-taught and use these applications in a particular field.

\subsection{An explanatory and descriptive study}

In this part of the study, the authors of the research questioned whether the digital competences of the respondents are adequate or not. In this way, a large part of the respondents of both countries stated that they have the right digital skills (90 Spain84 Czech Republic). However, a considerable number of respondents doubt their skills (39 Spain- 36 R. Czech).

The following results can be demonstrated: first, focusing on digital training skills, it can be emphasized that the average of the Spanish level is close to 3. However, the standard deviation shows decreasing values, confirming significant statistical differences in this case. Those items that have achieved the highest score are 19.1 (3.75) -for professionals- and 19.2 (3.61) - for students. While those lower values are related to items 19.3 (3.21) - for families - and 19.4 (3.23) - for the general public. In the Czech case, it is necessary to point out that the average is close to 2, affecting the decrease in the questionnaire score. However, the standard deviation has values close to one, so there are no significant statistical differences. Those items that have had the greatest impact have been 19.1 (3.05) - for professionals - and 19.2 (2.86) - for students. While those lower values are related to items $19.4(2.44)$ - for the general public - and 19.3 (2.26) - for families. In both cases, respondents point out the importance of acquiring the right digital competence for their studies and their working life. Likewise, for the Spanish respondents, this is more important than for Czech respondents (Table 2).

Secondly, considering what content is essential for the promotion of digital literacy, it can be confirmed that in the Spanish case, the average is close to 3. However, once again, the standard deviation shows remote values, affecting statistical differences significant. The best-rated items are item 20.6 (3.67) - Security in the dissemination of content - and 20.5 (3.62) - Security when producing content. On the other hand, the 
Table 2. Digital skills training

\begin{tabular}{|c|c|c|c|c|c|c|}
\hline & \multirow[b]{2}{*}{ Minimum } & \multirow[b]{2}{*}{ Maximum } & \multicolumn{2}{|c|}{ Spain } & \multicolumn{2}{|c|}{ Czech Republic } \\
\hline & & & Medium & $\begin{array}{l}\text { Standard } \\
\text { deviation }\end{array}$ & Medium & $\begin{array}{l}\text { Standard } \\
\text { deviation }\end{array}$ \\
\hline Ítem 19.1 & 1 & 4 & 3,75 & 0,506 & 3,05 & 1,098 \\
\hline Ítem 19.2 & 1 & 4 & 3,61 & 0,614 & 2,86 & 0,951 \\
\hline Ítem 19.3 & 1 & 4 & 3,21 & 0,772 & 2,26 & 0,77 \\
\hline Ítem 19.4 & 1 & 4 & 3,23 & 0,761 & 2,44 & 0,786 \\
\hline $\begin{array}{l}\mathrm{N} \text { valid (according } \\
\text { to list) }\end{array}$ & & & \multicolumn{2}{|c|}{146} & \multicolumn{2}{|c|}{146} \\
\hline
\end{tabular}

worst score corresponds to items 20.3 (3.23) - Knowledge of the language for content analysis and production - and 20.4 (3.32) - Information distribution. On the other hand, in the Czech case, the average rounded up is close, while there are no statistical differences concerning the standard deviation. The questions with the best results were items 20.4 (2.91) - Distribution of information - and 20.3 (2.82) - Knowledge of language for content analysis and production -. The least valued issues are related to items 20.2 (2.42) - Ethical and deontological values - and 20.6 (2.63) - Security in the dissemination of content.

Table 3. Promotion of digital literacy

\begin{tabular}{|c|c|c|c|c|c|c|}
\hline & & & \multicolumn{2}{|c|}{ Spain } & \multicolumn{2}{|c|}{ Czech Republic } \\
\hline & \multicolumn{2}{|c|}{ MinimumMinimum } & Medium & $\begin{array}{l}\text { Standard } \\
\text { deviation }\end{array}$ & Medium & $\begin{array}{l}\text { Standard } \\
\text { deviation }\end{array}$ \\
\hline Ítem 20.1 & 1 & 4 & 3,4 & 0,628 & 2,68 & 0,994 \\
\hline Ítem 20.2 & 1 & 4 & 3,39 & 0,8 & 2,41 & 0,849 \\
\hline Ítem 20.3 & 1 & 4 & 3,23 & 0,702 & 2,82 & 0,901 \\
\hline Ítem 20.4 & 1 & 4 & 3,32 & 0,682 & 2,91 & 0,915 \\
\hline Ítem 20.5 & 1 & 4 & 3,62 & 0,565 & 2,73 & 0,937 \\
\hline Ítem 20.6 & 1 & 4 & 3,67 & 0,54 & 2,63 & 0,913 \\
\hline $\begin{array}{l}N \text { valid (according } \\
\text { to list) }\end{array}$ & & & & & & \\
\hline
\end{tabular}

Analyzing the data, dissimilarity in the two countries can be observed: while Spanish respondents tend to give importance to security when creating and diffusing content, Czech respondents prioritize information distribution and linguistic competence (Table 3). The security of content production and diffusion are the least important aspect for the Czech respondents.

Thirdly, the authors of the research questioned what the respondents use the educational apps for. In Spain, the average shows values close to 2. However, the standard deviation does not show any significant differences with values close to 1 . The most ascending items are 21.2 (3.23) - Learn new things - and 21.4 (2.42) - In my personal life -. The descending items are $21.3(2.08)$ - To maintain social relationships - and 21.1. (2.34) - To entertain myself -. In the Czech Republic, the average is also immediate at two and the standard deviation at 1 , reaffirming that there are no significant statistical differences. The items with the best score are $21.2(2.85)-$ To learn new things - and 21.1. (2.34) - To entertain myself -. The items with the lowest score are $21.3(2.17)$ - To maintain social relationships - and $21.4(2.22)$ - In my personal life -. 
In short, it can be concluded that both countries agree to use the apps to learn and not as a tool for maintaining social relationships (Table 4).

Table 4. Usage of educational apps

\begin{tabular}{lcccccc}
\hline & & \multicolumn{3}{c}{ Spain } & & $\begin{array}{c}\text { Czech } \\
\text { Republic }\end{array}$ \\
& Minimum & Maximum & Medium & $\begin{array}{c}\text { Standard } \\
\text { deviation }\end{array}$ & Medium & Medium \\
\hline Ítem 21.1 & 1 & 4 & 2,34 & 1,032 & 2,34 & 1,029 \\
Ítem 21.2 & 1 & 4 & 3,23 & 0,93 & 2,85 & 1,096 \\
Ítem 21.3 & 1 & 4 & 2,08 & 1,031 & 2,17 & 1,016 \\
Ítem 21.4 & 1 & 4 & 2,42 & 1,002 & 2,22 & 1,002 \\
$\begin{array}{l}\text { N valid (according } \\
\text { to list) }\end{array}$ & & & 146 & & 146 \\
\hline
\end{tabular}

Further, analyzing the reasons why these apps are used, it can be noted that in the Spanish case, the average is close to 3 and the standard deviation to 1, showing that there are no significant statistical differences. Those best-rated items are related to 22.1 (3.09) - They help me to complement my studies - and 22.3 (3.08) - They are useful as a learning tool -. On the other hand, the lowest scores are $22.5(2.01)-$ I feel connected with other people - and 22.2. $(2,23)$ - They help me feel more secure -. In the Czech case, the average is close to 2 , causing a decrease in the questionnaire score. However, the standard deviation is correct, demonstrating that there are no significant statistical differences. The items with the greatest impact are 22.3 (2.73) - They are useful as a learning tool - and 22.1 (2.64) - They help me to complement my studies -. The items with the least effect are 22.5 (1.88) - I feel connected with other people - and 22.2 (2.19) - They help me feel more secure -. In summary, students of both nationalities score the same results, reaffirming the importance of educational apps for complementing their studies (Table 5).

Table 5. Reasons why students use educational apps

\begin{tabular}{|c|c|c|c|c|c|c|}
\hline & \multirow[b]{2}{*}{ Minimum } & \multirow[b]{2}{*}{ Maximum } & \multicolumn{2}{|c|}{ Spain } & \multicolumn{2}{|c|}{ Czech Republic } \\
\hline & & & Medium & $\begin{array}{l}\text { Standard } \\
\text { deviation }\end{array}$ & Medium & $\begin{array}{l}\text { Standard } \\
\text { deviation }\end{array}$ \\
\hline Ítem 22.1 & 1 & 4 & 3,09 & 0,968 & 2,64 & 1,096 \\
\hline Ítem 22.2 & 1 & 4 & 2,23 & 0,995 & 2,19 & 0,878 \\
\hline Ítem 22.3 & 1 & 4 & 3,08 & 0,951 & 2,73 & 1,053 \\
\hline Ítem 22.4 & 1 & 4 & 2,56 & 1,003 & 2,29 & 0,965 \\
\hline Ítem 22.5 & 1 & 4 & 2,01 & 0,91 & 1,88 & 0,928 \\
\hline Ítem 22.6 & 1 & 4 & 2,7 & 0,957 & 2,2 & 0,94 \\
\hline Ítem 22.7 & 1 & 4 & 2,95 & 0,949 & 2,25 & 0,897 \\
\hline $\begin{array}{l}\mathrm{N} \text { valid (according } \\
\text { to list) }\end{array}$ & & & \multicolumn{2}{|c|}{146} & \multicolumn{2}{|c|}{146} \\
\hline
\end{tabular}

The average for the most downloaded apps in Spain has values close to 2 generating a decrease in the questionnaire score. However, the standard deviation does not show significant statistical differences. The apps that have obtained the best response are those related to items 20.4 (3.20) - Kahoot -, 20.5 (2.78) - Google Classroom - and 20.1 (2.40) - Duolingo -. However, the apps that have achieved lower values are items 20.9 (1.80) - PlanSnap -, 20.11 (1.87) - iPasen - and 20. 3 (1.89) - Photomath -. These 
results clarify that Spanish students prefer applications related to languages, subject reinforcement, and blended learning (Table 6).

Table 6. Educational apps in Spain

\begin{tabular}{lcccc}
\hline & Minimum & Maximum & Medium & $\begin{array}{c}\text { Standard } \\
\text { deviation }\end{array}$ \\
\hline Ítem 23.1 & 1 & 4 & 2,4 & 1,086 \\
Ítem 23.2 & 1 & 4 & 1,97 & 0,932 \\
Ítem 23.3 & 1 & 4 & 1,89 & 0,888 \\
Ítem 23.4 & 1 & 4 & 3,2 & 1,001 \\
Ítem 23.5 & 1 & 4 & 2,78 & 1,16 \\
Ítem 23.6 & 1 & 4 & 2,07 & 1,106 \\
Ítem 23.7 & 1 & 4 & 2,08 & 1,086 \\
Ítem 23.8 & 1 & 4 & 2,18 & 1,061 \\
Ítem 23.9 & 1 & 4 & 1,8 & 0,86 \\
Ítem 23.10 & 1 & 4 & 1,95 & 0,945 \\
Ítem 23.11 & 1 & 4 & 1,87 & 0,934 \\
Ítem 23.12 & 1 & 4 & 1,99 & 1,024 \\
Ítem 23.13 & 1 & 4 & 1,98 & 1 \\
Ítem 23.14 & 1 & 4 & 2,27 & 1,097 \\
Ítem 23.15 & 1 & 4 & 2,05 & 1,059 \\
N valid (according to list) & & & & 146 \\
\hline
\end{tabular}

The average for the most downloaded apps in the Czech Republic is close to 2, and the standard deviation is high, confirming that there are no significant statistical differences. Therefore, taking into consideration the best-rated items, you can delimit 24.1 (2.69) - Duolingo - 24.9 (2.63) - Kahoot - and 24.10 (2.56) - Quizlet -. On the other hand, those items with the lowest valuation are 24.12 (1.84) - Mořské panny -, 24.6 (1.87) - PlantNet - and 24.5 (1.89) - Minecraft Education edition-. Similarly, to the Spanish students. Czech students prefer language-related apps, subject reinforcement, as well as learning-based apps (Table 7).

\section{DISCUSSION AND CONCLUSIONS}

The increasing number of communication technology and the proliferation trend worldwide, especially in the European context, allowed us to assess the knowledge and attitude of university students to educational applications.

ICT, as it has been verified throughout this investigation, hold an important place in people's lives. Besides, Spain ranks among the top European countries where the purchase of Smartphones and downloaded applications is rapidly rising (Informe del estado de las apps en España "The App Date", 2011). According to the report mentioned above, Spanish people use applications more than they use the Web. The report also presents a typical user profile, which was made in 2011. According to this report, a typical user is a middle- or upper-class man, who comes from a town and is between 25 and 40 years old. The user has about 20 downloaded applications on their Smartphone and uses them more than once a day. The figures of this research characterize an average respondent as a woman between 18 and 24 years, enrolled in a degree in education who uses an Android Smartphone 3 hours a day. An average Spanish respondent uses their device mostly at home to maintain social relationships and entertainment. In contrast, an average Czech respondent uses their mobile device 
Table 7. Educational apps in the Czech Republic

\begin{tabular}{lcccc}
\hline & Minimum & Maximum & Medium & Standard deviation \\
\hline Ítem 24.1 & 1 & 4 & 2,69 & 1,073 \\
Ítem 24.2 & 1 & 4 & 2,21 & 0,992 \\
Ítem 24.3 & 1 & 4 & 2,29 & 1,049 \\
Ítem 24.4 & 1 & 4 & 2,18 & 0,988 \\
Ítem 24.5 & 1 & 4 & 1,89 & 1,02 \\
Ítem 24.6 & 1 & 4 & 1,87 & 0,854 \\
Ítem 24.7 & 1 & 4 & 1,96 & 0,906 \\
Ítem 24.8 & 1 & 4 & 2,21 & 0,961 \\
Ítem 24.9 & 1 & 4 & 2,63 & 1,125 \\
Ítem 24.10 & 1 & 4 & 2,56 & 1,068 \\
Ítem 24.11 & 1 & 4 & 2,15 & 0,988 \\
Ítem 24.12 & 1 & 4 & 1,84 & 0,975 \\
Ítem 24.13 & 1 & 4 & 1,97 & 0,877 \\
Ítem 24.14 & 1 & 4 & 1,97 & 0,902 \\
Ítem 24.15 & 1 & 4 & 2,44 & 1,031 \\
N valid (according to list) & & & & 146 \\
\hline & & & & \\
\hline
\end{tabular}

to seek information. In addition, it is a student who knows and understands what an educational application is and who downloads between 2 and 3 onto their mobile device. In the Spanish case, they do not use educational applications frequently, while in the Czech case, they use educational applications once a week. They are self-taught and use these applications in a field. On the other hand, the figures detect a lack of training in how to use the educational applications for learning or complementing studies such as languages, subject reinforcements, and blended learning.

In addition to the collected data, it should be mentioned that «the use of apps has increased by $111 \%$ in the last three years, from which only by $11 \%$ in 2015 and 2016 (Ditrendia, 2017, p. 36). This has caused a massive increase in downloads that is confirmed in this research. At the same time, this trend could be dangerous as «the unstoppable development of the multiple applications of digital technology is leading to disregard the concept of technology as a set of knowledge and tools and to focus on digital artifacts» (Sancho-Gil, 2019, p.9).

The focus on tools requires educational intervention and user training. In this sense, there is an appellation on digital literacy that favors the development of digital competence/literacy (INTEF, 2017) so people will become "prosumers" rather than users (Sánchez-Carrero and Contreras, 2012). The figures gathered in this study reflect a need for training, both in Spain and the Czech Republic. Moreover, there should be a record of the downloaded applications not only in Spain and the Czech Republic but also in other countries. The analyzed data also prove that in both countries, students prefer game-based applications designed for language learning. These applications are very convenient for improving digital skills and abilities.

As indicated throughout the investigation, it is necessary to rethink the current education and methodologies in order to achieve curricular objectives. Also, while reviewing the curriculum, it was noted that there is a clear lack of involvement of educational policies, which are seen as "old fashioned" methodologies and little practice for teaching in the digital era. As indicated more than five years ago, "The document of the Commission and Parliament suggests a need for inclusion of literacy in the curricula and a need for educational projects such as a research» (Caldeiro-Pedreira, 
2013). Nevertheless, years later, the situation has not changed much, and digital literacy occurs rather on a self-taught basis. Therefore, the demand is clear in both two analyzed Spanish and Czech contexts. There is a lack of educational policies that would systematize and operationalize learning with educational applications.

In addition, it is evident that both countries lack training for literacy and the development of digital competencies. The website of the Teacher Training Center of Castilla La Mancha defines educational training programs as "a constant update of digital competence that these days is required from teaching professionals" (CRFP, 2019). The statement shares the opinion of the general public about the present situation when the ways of acquiring knowledge are unlimited. According to Castaneda and Selwyn (Castañeda \& Selwyn, 2018), an effective bridge between theory and practice, especially in higher education, synthesizes contents in a practical way, which is similar to our experience in immediate reality.

In other words, this means that in reality, more conventional teaching methods should be applied. For this purpose, a system connecting literacy and the development of digital competencies should be established for teachers and students. Illich and Sanders (1988) presented their dream where literacy is not merely reduced to a system of signs that isolate words. Therefore, technology advancement and the use of multiple devices require a shift in aptitude that would modify and support educational laws and regulatory frameworks. To conclude, the results of this research indicate that Spanish - Czech university students should be primarily taught how they could benefit from using new digital tools and how to use them in a meaningful way.

In the described context and how the data marks, lifelong learning (UNESCO, n.d.) is essential because it makes it possible to update both teachers and students. It also enables them to develop skills (OECD, SFSO, \& DeSeCo, 2001) and competences that bet not only for the knowledge link to the knowledge of applications but also for the know-how. Skills that enable life in society, and they allow citizens intercommunication in general and particularly in the youngest population. On the other hand, the literacy of the user that must abandon the passive role of a mere receiver to become a "prosumer" (Sánchez-Carrero \& Contreras-Pulido, 2012), that is to say, an active, creative and motivated user, is essential. A subject who cans survive, not only, in the digital society but also in the context where the continuous emergence of applications prevails.

\section{REFERENCES}

Aguaded, I. (2014). From Infoxication to the Right to Communicate. Comunicar, 21(42), 07-08. https://dx.doi.org/10.3916/c42-2014-a1

Albaladejo-Ortega, S., \& Sánchez-Martínez, J. (2019). El ecosistema mediático de la ficción contemporánea: relatos, universos y propiedades intelectuales a través de los transmedial worlds. Icono, 14(1), 15-38. https://doi.org/10.7195/ri14.v17i1.1241

Bizelli, J. L. (2017). Innovación y Educación en la sociedad digital. III Congreso internacional de Transformación Educativa (Vol. 1). Retrieved from https://tinyurl.com/y3x4eaoe

Buendía, L., Colás, M., \& Hernández, F. (1998). Métodos de investigación en psicopedagogía. Madrid: McGraw-Hill.

Caldeiro-Pedreira, M. C. (2013). Desarrollo curricular de la competencia mediática en educación secundaria en la comunidad gallega. EDMETIC, 2(2), 8-36. https://dx.doi.org/10.21071/edmetic.v2i2.2868

Caldeiro-Pedreira, M. C., \& Aguaded-Gómez, I. (2015). "Estoy aprendiendo, no me molestes" la competencia mediática como forma de expresión crítica de nativos e inmigrantes digitales. REDES.com. Revista de Estudios para el Desarrollo Social de la Comunicación, 12, 25-44. https://doi.org/10.15213/redes.n12.p25 
Canavilha, J. (2011). El nuevo ecosistema mediático. Index.comunicación, 1(1), 13-24. Retrieved from http://journals.sfu.ca/indexcomunicacion/index.php/indexcomunicacion/article/view/4

Carolina-Martí, M., Agostino, M. J. D., de Cabo, J. V., \& Sanz-Valero, J. (2008). Alfabetización Digital: un peldaño hacia la sociedad de la información. Medicina y Seguridad del Trabajo, 54(210), 11-15. https://dx.doi.org/10.4321/s0465-546x2008000100003

Castañeda, L., \& Selwyn, N. (2018). More than tools? Making sense of the ongoing digitizations of higher education. International fournal of Educational Technology in Higher Education, 15(22), 1-10. https://dx.doi.org/10.1186/s41239-018-0109-y

CRFP. (2019). Competencia digital II: APP's en Google Suite for Education y nuevas herramientas de capacitación digital para el aula (Edición 1). Retrieved from http://centroformacionprofesorado.castillalamancha.es/comunidad/crfp/recurso/ competencia-digital-ii-apps-en-google-suite-for/ 009489f3-2c53-4ad3-ab11-be8da31dbcb5

Ditrendia. (2017). Informe Mobile en España y en el mundo 2017. Retrieved from https://bit.ly/2ogkwQ1

Fernández-García, N., Blasco-Duatis, M., \& Caldeiro-Pedreira, M. (2016). Communication and Education by Transmedia. Report on ICT skills in four secondary schools in Europe. Cuadernos Artesanos de Comunicación(108). Retrieved from http://www.cuadernosartesanos.org/2016/CAC-108-INGLES.pdf

García-García, A., \& Rey-Barbáchano, R. (2012). Las apps en el aula del siglo XXI (No. 259-260). Retrieved from http://www.centrocp.com/las-apps-en-el-aula-del-siglo-xxi/

García-Ruiz, R., Ramírez-García, A., \& Rodríguez-Rosell, M. M. (2014). Media Literacy Education for a New Prosumer Citizenship. Comunicar, 22(43), 15-23. https://dx.doi.org/10.3916/c43-2014-01

Gardner, H., \& Davis, K. (2014). La generación APP. Cómo los jóvenes gestionan su identidad, su privacidad y su imaginación en el mundo digital. Barcelona: Paidós.

George, D., \& Mallery, P. (2003). SPSS for Windows Step by Step: A Simple Guide and Reference. 11.0 Update. Boston: Allyn \& Bacon.

Gozálvez, V. (2015). Ciudadanía mediática. Una mirada educativa. Madrid: Dyckinson.

Granado-Palma, M. (2019). Educación y exclusión digital: los falsos nativos digitales. Revista de estudios socioeducativos : $\operatorname{RESED}(7), 27-41$.

https://dx.doi.org/10.25267/rev_estud_socioeducativos.2019.i7.02

Hernández-Serrano, M.-J., Renés-Arellano, P., Graham, G., \& Greenhill, A. (2017). From Prosumer to Prodesigner: Participatory News Consumption. Comunicar, 25(50), 77-88. Retrieved from https:/dx.doi.org/10.3916/c50-2017-07 10.3916/c50-2017-07

Ibañez-Etxeberría, A., Kortabitarte, A., Castro, P. D., \& Gillate, I. (2019). Competencia digital mediante apps de temática patrimonial en el marco DigComp. Revista Electrónica Interuniversitaria de Formación del Profesorado, 22(1), 13-27. http://dx.doi.org/10.6018/reifop.22.1.356231

Illich, I., \& Sanders, B. (1988). ABC. Alphabetization of the Popular Mind. London: Marion Boyars Publishers.

Informe del estado de las apps en España "The App Date”. (2011). Retrieved from https://www.amic.media/media/files/file_352_1289.pdf

INTEF. (2017). Marco Común de Competencia Digital Docente. Retrieved from https://aprende.intef.es/sites/default/files/2018-05/ 2017_1020_Marco-Com\%C3\%BAn-de-Competencia-Digital-Docente.pdf

MECD. (2018). Dictamen 11/2018 al Proyecto de orden por la que se desarrolla el Marco de Competencia Digital Docente. Retrieved from https:/www.educacionyfp.gob.es/dam/ jcr:a23f155c-64f6-4e25-b0b7-22b80920fd92/Dictamen_11_2018.pdf

Noguera-Fructuoso, I. (2015). Cómo los millennials están cambiando el modo de aprender: estado del arte de la integración de las TIC en educación. RIED. Revista Iberoamericana 
de Educación a Distancia. RIED, 18(1), 45-65. https://doi.org/10.5944/ried.18.1.13800 OECD, SFSO, \& DeSeCo. (2001). Definition and Selection of Competencies: Teorethical and conceptual foundation (DeSeCo). Retrieved from

http://www.oecd.org/education/skills-beyond-school/41529556.pdf

Ramírez-Mera, U. N., \& Barragán-López, J. F. (2018). Autopercepción de estudiantes universitarios sobre el uso de tecnologías digitales para el aprendizaje. Apertura, 10(2), 94-109. http://dx.doi.org/10.18381/ap.vl0n2.1401

Replantear las capacidades en alfabetización en un mundo digital. (2017, 09 08). Retrieved from https://es.unesco.org/news/replantear-capacidades-alfabetizacion-mundo-digital

Rodrigo-Cano, D., Gómez, I. A., \& García-Moro, F. J. (2019). Metodologías colaborativas en la Web 2.0. El reto educativo de la Universidad. REDU. Revista de Docencia Universitaria, 17, 229-229. https://dx.doi.org/10.4995/redu.2019.10829

Sánchez-Carrero, J., \& Contreras-Pulido, P. (2012). De cara al prosumidor: producción y consumo empoderando a la ciudadanía 3.0. Revista ICONO14. Revista científica de Comunicación y Tecnologías emergentes, 10(3), 62-84.

https://dx.doi.org/10.7195/ri14.v10i3.210

Sánchez-López, I., Pérez-Rodríguez, A., \& Fandos-Igado, M. (2019). Com-educational Platforms: Creativity and Community for Learning. Fournal of New Approaches in Educational Research, 8(2), 214-214. https://dx.doi.org/10.7821/naer.2019.7.437

Sancho-Gil, J. M. (2019). De la tecnología para aplicar a la tecnología para pensar: implicaciones para la docencia y la investigación. Revista Latinoamericana de Tecnología Educativa. RELATEC, 18(1), 9-24. http://orcid.org/0000-0002-2941-5619

UNESCO. (n.d.). Santiago. Oficina Regional de Educación para América Latina y el Caribe. Retrieved from https://es.unesco.org/fieldoffice/santiago

Unionews. (2016, 08 25). La generación App. [Blog post]. Retrieved from https://bit.ly/2nUoFvw

Vuorikari, R., Punie, Y., Carretero-Gomez, S., \& Van-Den-Brande, G. (2016). DigComp 2.0: The Digital Competence Framework for Citizens. Sevilla: European Union.

https://doi.org/10.2791/607218 